\title{
'Leger est aprendre mes fort est arendre': wool, debt, and the dispersal of Pipewell Abbey (1280-1330)
}

Article

Accepted Version

Bell, A. R., Brooks, C. and Dryburgh, P. R. (2006) 'Leger est aprendre mes fort est arendre': wool, debt, and the dispersal of Pipewell Abbey (1280-1330). Journal of Medieval History, 32 (3). pp. 187-211. ISSN 0304-4181 doi:

https://doi.org/10.1016/j.jmedhist.2006.07.001 Available at https://centaur.reading.ac.uk/20505/

It is advisable to refer to the publisher's version if you intend to cite from the work. See Guidance on citing.

Published version at: http://dx.doi.org/10.1016/j.jmedhist.2006.07.001

To link to this article DOI: http://dx.doi.org/10.1016/j.jmedhist.2006.07.001

Publisher: Elsevier

All outputs in CentAUR are protected by Intellectual Property Rights law, including copyright law. Copyright and IPR is retained by the creators or other copyright holders. Terms and conditions for use of this material are defined in the End User Agreement.

www.reading.ac.uk/centaur 
Central Archive at the University of Reading

Reading's research outputs online 
NOTICE: this is the author's version of a work that was accepted for publication in the Journal of Medieval History. Changes resulting from the publishing process, such as peer review, editing, corrections, structural formatting, and other quality control mechanisms may not be reflected in this document. Changes may have been made to this work since it was submitted for publication. A definitive version was subsequently published in the Journal of Medieval History, 32.3 (2006), DOI: 10.1016/j.jmedhist.2006.07.001 


\section{'Leger est aprendre mes fort est arendre':}

\section{Wool, Debt, and the Dispersal of Pipewell Abbey (1280-1330). Adrian R Bell, Chris Brooks and Paul Dryburgh*}

\section{$\underline{\text { Abstract }}$}

It has long been known that English Cistercian monasteries often sold their wool in advance to foreign merchants in the late thirteenth century. The abbey of Pipewell in Northamptonshire features in a number of such contracts with Cahorsin merchants. This paper looks again at these contracts in the context of over 200 other such agreements found in the governmental records. Why did Pipewell descend into penury over this fifty year period? This case study demonstrates that the promise of ready cash for their most valuable commodity led such abbots to make ambitious agreements - taking on yet more debt to service existing creditors - that would lead to their eventual bankruptcy.

\footnotetext{
* Dr Adrian R Bell, ICMA Centre, The University of Reading, Whiteknights, Reading, RG6 6BA email: a.r.bell@ @rdg.ac.uk (address for correspondence); Professor Chris Brooks, CASS Business School; Dr Paul Dryburgh, Kings College London. The authors gratefully acknowledge financial support for this research from the ESRC under grant RES-000-22-0647. An in-depth analysis drawing on this project, including further discussion of Pipewell as a case study, will be presented in Adrian R. Bell, Chris Brooks and Paul Dryburgh, The English Wool Market c. 1250-1350, Cambridge University Press (Forthcoming).
} 
'Remember dearest brethren and reverend fathers that by the said recognisances and due to seven years of dearth and common murrain of beasts, the goods of the house of Pipewell had been so exhausted that nothing remained for the meagre sustenance of the monks; sometimes they sat in the refectory for three or four days with only black bread and potage, at other times they wandered from market to market to buy bread, and this they patiently endured. I, the wretch and sinner who have occupied the place of abbot, therefore counsel, ask, implore, and warn in as much as I am able, lest another abbot fall so deeply into the hands of Lombards, that they heed the French maxim "leger est aprendre mes fort est a rendre.",

Here, in the words of William of Lawford, the recently deposed abbot of the Cistercian monastery of Pipewell in Northamptonshire ${ }^{2}$, we have a most distressing English witness to the agrarian calamity sweeping Europe in the early fourteenth century. This candid mixture of apology and exhortation, moreover, resonates in the crises of monastic finance prevalent over the previous fifty years and emphasises human frailty over environmental factors in the accumulation of the debts responsible for the three-year dispersal of the convent 'pretextu paupertatis' in September 1323. ${ }^{3}$ How did such frailty manifest itself?

Crammed onto a blank folio of a late-thirteenth century cartulary, Lawford's lament conspicuously follows a list of fifteen recognisances for debt, totalling around £2400, amassed since 1314. Most relate to wool that his predecessors had sold but struggled to deliver. Prepared to the highest standard,

Cistercian wool encouraged merchants from across Europe to invest huge amounts of capital to fuel the burgeoning luxury cloth trade in the Low Countries. Business partners exchanged vast numbers of sacks

\footnotetext{
1 'It is easy to take but hard to give': London, British Library, Stowe MS 937, f. 143v., 'Memorandum fratres carissimi patresque reverendi quod per predicas recogniciones et propter vij annorum sterilitates et per communem morinam bestiarum, bona domus de Pipewell' adeo fuerunt consumpta, que eorum residuum non sufficiebat ad exilem dicte domus monachorum sustentacionem, set aliquando sedebant in refectorio per iii vel iiij dies cum nigro pane et potagio tantum et aliquando emebant panem suum de foro ad forum, et hoc omnia pacienter sustinuerunt. Hinc est quod ego miser et precator qui aliquando occupavi locum abbatis consulo, rogo, supplico, et quatenus possum moneo ne aliquis abbas de cetero ita profunde concidat in manus Lumbaudorum, quia gallice dicitur leger est aprendre mes fort est arendre.'

${ }^{2}$ William was deposed on 24 April 1323: BL Cotton MS Otho B xiv, f. 161r.

${ }^{3}$ BL Cotton MS Otho B xiv, f. 150r.
} 
for delivery within a few months or even up to twenty years with large cash advances. Historians of both the English and the monastic economy have long suggested that, in exploiting their most lucrative asset on local and international markets, Cistercian abbots dynamised English export trade and credit networks, particularly in the half-century either side of 1300 . But such agreements led the abbots to enter a vicious circle where such advances - generally viewed as loans against the security of wool - initially sunk into building and maintenance expenses and meeting royal and papal tax demands, increasingly serviced debts accumulated by previous unpaid advances. ${ }^{4}$ Virulent sheep disease struck four times between 1258 and 1317 , ravaging flocks, reducing supplies of wool available for the market, and so threatening to sever the credit links feeding the monastic economy in Britain. ${ }^{5}$

For some monastic historians such transactions epitomised the alienation of the Cistercian Order from the original 'ideals' of seclusion and self-sufficiency established in the twelfth century. ${ }^{6}$ Extensive credit relationships potentially embroiled abbots in usury, as wool contracts often disguised hidden interest charges ${ }^{7}$, promoting accusations of greed and financial mismanagement. Dispersal, became a fate common to several English Cistercian monasteries in the late-thirteenth and early-fourteenth centuries. ${ }^{8}$ Kirkstall and Rievaulx (Yorks.) dispersed in 1281 and 1292 respectively, while the General Chapter received petitions to that end from Vaudey (Lincs.) in 1280, Flaxley (Gloucs.) in 1281, Fountains (Yorks.) in 1291, and Bruern (Oxon.) in 1293..$^{9}$ Coburn Graves, however, argues that dispersal was not

\footnotetext{
${ }^{4}$ R.J. Whitwell, 'English Monasteries and the Wool Trade in the $13^{\text {th }}$ Century,' Vierteljahrschrift für Sozial- und Wirtschaftsgeschichte 2 (1904), 1-33; R.A. Donkin, The Cistercians: Studies in the Geography of Medieval England and Wales (Toronto, 1978), 17; T.H. Lloyd, The Wool Trade in Medieval England (Cambridge, 1978), 288-312.

${ }^{5}$ Ian Kershaw, 'The Great European Famine and Agrarian Crisis in England, 1315-1322,' Past \& Present 59 (1973), 27.

${ }^{6}$ David Knowles, The Religious Orders in England, II (Cambridge, 1948), 68; J.E. Madden, 'Business Monks, Banker Monks, Bankrupt Monks: The English Cistercians in the Thirteenth Century,' Catholic Historical Review 49 (3) (1963), 341-64.

${ }^{7}$ Our own research into these 'forward' contracts has demonstrated that interest was being charged at a level of between $17 \%$ and 20\% - which would appear to be reasonable for this period. For a summary of these findings see Adrian R. Bell, Chris Brooks and Paul R. Dryburgh, 'Why forwards really came from the past', Professional Investor (April 2005), 22-26 and for more detail, 'Interest Rates and Efficiency in Medieval Wool Forward Contracts', Journal of Banking and Finance (Forthcoming).

${ }^{8}$ It has been shown that as a reaction to the agrarian crisis, dispersal was a continental wide issue for monasteries in the early fourteenth century. For instance, the Cistercian Abbey's of Villers at Tilly in Brabant and Val Saint-Lambert in Liégeois were dispersed between 1315-1316: William Jordan, The Great Famine: Northern Europe in the Early Fourteenth Century (Princeton, 1996), 70-71.

${ }^{9}$ Guy Barnes, Kirkstall Abbey, 1147-1539: An Historical Study (Leeds: Publications of the Thoresby Society, LVIII, no. 128, 1984), 43-5; Statuta Capitulorum Generalium Ordinis Cisterciensis ab anno 1116 ad annum 1786, ed. J. Canivez (Louvain, 1934), III, 202 (1280: 44), 215 (1281: 63), 258 (1291: 61 (Rievaulx), 62 (Fountains), 266 (1293: 31).
} 
the penalty it appeared and represented 'a normal event, even if an unhappy one' in Cistercian history. ${ }^{10}$ Sanctioned by the Cistercian General Chapter, dispersal reduced ordinary expenditure and released resources for debt resettlement by sending the brethren to seek sustenance in other houses of the Order. ${ }^{11}$ Whilst essentially therefore a temporary resort, rarely have the often tortuous processes and myriad combination of factors creating penury, or the undulations between indebtedness, recovery, and disaster, been charted in detail.

In a recent examination of the wool sales which crippled Rievaulx abbey in the late-thirteenth century, Emilia Jamroziak, however, concludes that the abbey's economy and future financial wellbeing were bound inextricably to raising credit through wool regardless of the short-term damage this wrought. ${ }^{12}$ Rievaulx, of course, one of the great Yorkshire houses of international renown, enjoyed sprawling pastures suitable for grazing thousands of sheep and forged business contacts with Florentine and Lucchese merchant courtiers. However, not all Cistercian houses were as suited to large-scale wool production or to consistently luring Italian silver. Pipewell, a house of lesser means, was one such place. Nevertheless, successive abbots forged an infamous business partnership with a group of southern French merchants, which became ingrained into the abbey's economic fabric for over five decades. Oscillating between profitability and financial paralysis, and threatening dispersal in 1296 and 1328, its ramifications dictated abbatial policy and possibly transcended the profit-driven motives of many such deals. This article examines the creation, development, and consequences of this partnership from a wide variety of sources, investigating mechanisms of trade, indebtedness, and debt resolution, and assesses whether an unwillingness to forsake its potential plunged Pipewell into the financial morass.

Last-listed of Lawford's fifteen recognisances is a bond for $£ 213$ and twenty-two sacks of wool owed to William Servat of Quercy. This represented the arrears of the most famous advance wool contract

\footnotetext{
${ }^{10}$ C.V. Graves, 'The Economic Activities of the Cistercians in medieval England (1128-1307), Analecta Sacri Ordinis Cisterciensis 13 (1957), 37.

${ }^{11}$ L.J. Lekai, The Cistercians: Ideals and Reality (Dallas, 1977), 304-5. In 1189 the General Chapter stipulated convents could only be dispersed by 'due investigation and authorization', an order reiterated in 1269: Statuta, I: 114 (1189: 18), III: 71 (1269: $15)$.

${ }^{12}$ Emilia Jamroziak, 'Rievaulx Abbey as a Wool Producer in the Late Thirteenth Century: Cistercians, Sheep, and Debts,' Northern History XL: 2 (September 2003), 197-218.
} 
from a surviving corpus of well over 200 documents. ${ }^{13}$ On 28 February 1291, the verdict of a panel of arbitration convened by Edward I to settle a dispute between John de Hillun, abbot of Pipewell, and a partnership of the Cahorsin merchants Arnaud de Soliz, Jean de Redole, Gerard de Briole and William Servat, concerning breach of a wool contract, was enrolled onto the Close Rolls of the English chancery. ${ }^{14}$ Subsequently published in calendar form ${ }^{15}$, this has regularly attracted the attention of historians because the restructured contract, whilst sharing basic elements with contemporary agreements, has unique features which provide a window into the medieval woollen industry and monastic credit. ${ }^{16}$ Only T.H. Lloyd, however, traced the original contract drafted twenty-six months earlier, and it is these details that must guide the discussion.

On 12 November 1288, John de Hillun bound himself to deliver 360 sacks to the Cahorsins over the next fifteen years. ${ }^{17}$ Nine sacks of good wool, three sacks of middle-grade, seven of locks (the straggly parts of the fleece that fell from the sheep before shearing $)^{18}$, and five of tayller ${ }^{19}$ wool made up each annual delivery. Priced at eighteen marks in the first five years and twenty-one marks thereafter, good wool would be delivered each year on 22 July at the Boston fair, along with middling wool priced at twelve-and-a-half marks for the first five years and fourteen thereafter, locks priced initially at ten marks and then at thirteen, and tayller priced at twelve marks per sack only in the final ten years. In return, the merchants agreed to pay a series of complex advances to be offset against the delivery of wool and to provide a tun of wine each year. Two initial advances of $£ 120$ (in earnest money) and $£ 160$ (as a loan) had been forwarded before the enrolment, which were to be allowed to the merchants annually in the delivery of wool. Additional advances of $£ 636 s .8 d$. and $£ 736 s .8 d$. were to be made on Sunday after

\footnotetext{
${ }^{13}$ While such agreements have been common currency for over a century, the extent of the surviving corpus - over one-third of which concerns Cistercian abbeys - has never been fully collated. This omission will soon be rectified: Advance Contracts for the Sale of Wool in Medieval England, c. 1200-1330, ed. A. R. Bell, C. Brooks \& P. Dryburgh (List \& Index Society, 2006) and available online as study no. 5325 in the UK Data Archive catalogue at: www.data-archive.ac.uk. Pipewell is featured as the selling party in eight of these contracts. The monastic growers outstrip lay growers in these contracts, agreeing to supply 5330 sacks as opposed to just 843 sacks.

${ }^{14}$ London, The National Archives, C 54/108, mm. 8d.-9d. Also E 159/64, rot. 10; E 368/62, rot. 14. All subsequent references are to TNA documents unless stated. Advance Contracts, no. 133.

${ }_{15}^{15}$ Calendar of the Close Rolls preserved in the Public Record Office, 1288-96 (London, 1904), 192-5.

${ }^{16}$ Graves, 'Economic Activities,' 31-3; Lloyd, Wool Trade, 295-6.

${ }^{17}$ E $159 / 62$, rot. 4. Advance Contracts, no. 110.

18 'que cadent de ovibus in locacione et ante tonsionem'.

${ }^{19}$ Wool pressed into the common wool: 'brusetur inter communem lanam.'
} 
Martinmas and Sunday after Easter each year. The monks were to accommodate the merchants' dresser who was to supervise the clip and prepare it for delivery. They were to receive and husband 733 sheep provided by the merchants, who would contribute half of their maintenance costs with the intention that both the wool and any issue would be split between the two parties annually. At the end of the contract, all surviving sheep and the profits of their sale would be divided equally.

Second in quantity only to the 400 sacks sold by the Cluniac prior of Lewes to the Riccardi of Lucca, this contract was potentially the most lucrative of all surviving agreements. ${ }^{20}$ For wool valued at $£ 3445$, the Cahorsins paid $£ 280$ upfront and promised a further $£ 2050$ in advance over the course of the contract, leaving them a final $£ 1115$ to settle at $£ 746 s .8 d$. a year. Why, though, did the monks incur such an enormous debt if only two years later they were unable to deliver? Why did the merchants invest so much capital when problems must already have been evident? Both the contract itself and the factors promoting it provide the key.

Before moving on, though, it is important to place these contracts within the corpus of evidence for the history of the abbey's involvement with wool. Governmental sources allow the processes of trade and credit to be followed closely. The exchequer court, in particular, seems to have been the primary mechanism employed by foreign merchants in registering contracts and prosecuting defaulters, and its Plea (E 13) and Memoranda Rolls (E 159, 368) supply a rich paper trail. Pipewell abbey itself had a productive scriptorium. Three cartularies survive from the mid-late thirteenth century. ${ }^{21}$ A further register was probably in the process of compilation throughout the thirteenth and early-fourteenth centuries as Lawford's scrawl confirms. ${ }^{22}$ Perhaps the most important is a chronicle and register of documents compiled towards the middle of the fourteenth century either by, or for, Abbot Nicholas $(1323-50){ }^{23}$ It needs to be treated with caution, for its purpose seems to be to exonerate Nicholas from blame for the dispersal, which he had overseen, and also, in its opening tirade, for the destruction of the

\footnotetext{
${ }^{20}$ E 159/61, rot. 14 (Michaelmas term 1287). Advance Contracts, no. 104.

${ }^{21}$ BL Cotton MS Caligula A XII, ff. 2-159v.; A XIII; Additional MS 37022.

${ }^{22}$ BL Stowe MS 937.

${ }^{23}$ BL Cotton MS Otho B xiv, ff. 150r-205r. It must have been completed by 1343, as a different hand inserts evidence concerning a plea not resolved until that year: f. 196v.
} 
abbey's woodland over the past 180 years. ${ }^{24}$ It is therefore coloured by the compiler's experiences of the harshness of existence brought on by debt and famine and by an attempt to counter dissent in the convent in the mid-1330 ${ }^{25}$ by pinning the blame principally on William Lawford. ${ }^{26}$ It is, however, our sole surviving narrative. The compiler had access to, and employed, previous abbots' annual account rolls, cellarers' stock accounts and bursars' rolls, which have now been lost. ${ }^{27}$ His distillation of information mined from surviving muniments is dextrous and his evidence concerning recognisances and land transfers can be independently corroborated. Its survival makes Pipewell's experiences with debt and the wool trade arguably the best documented house in England.

Like many other houses of the Order, sheep farming was naturally concomitant with the abbey's foundation and development. ${ }^{28}$ Sited on the fringes of Rockingham forest, Pipewell, with its heavy clay soils, was not wholly conducive to arable cultivation and fostered a mixed economy. ${ }^{29}$ While Pipewell's founders in 1143 sought seclusion and the self-sufficient existence dictated by the early capitula of the Order, which condoned solely manual labour, animal husbandry and the tilling of the soil, its estates could not always meet the subsistence needs of the community. ${ }^{30}$ Though the late-twelfth and thirteenth centuries witnessed considerable forest clearance and assarting of land to extend the area under cultivation $^{31}$, frequently in the late-thirteenth and early-fourteenth centuries abbots had to buy grain to sustain the convent. During the Barons' War, the abbot of Croxden (Staffs.) sold Abbot Gerard (1256-9) all of his grain at Tugby (Leics.) for one year. From 1308-11, the monks regularly purchased poor-grade grain at high prices. ${ }^{32}$ Moreover, although successive abbots contravened Cistercian legislation

\footnotetext{
${ }^{24}$ BL Cotton MS Otho B xiv, ff. 150r.-151v., 197r.

${ }^{25}$ A reference survives, for example, to complaints about a lack of firewood in winter: f. 159r.

26 'qui non bene se habuit in regimine domus': f. 197r.

${ }^{27}$ BL Cotton MS Otho B xiv, ff. 151v., 158v., 161r., 161v.

${ }^{28}$ Donkin, Cistercians, 68-73.

${ }^{29}$ Glenn Foard, 'Medieval Woodland, Agriculture and Industry in Rockingham Forest, Northamptonshire,' Medieval Archaeology 45 (2001), 41-97.

${ }^{30}$ Lekai, The Cistercians, 26.

${ }^{31}$ BL Cotton MS Otho B xiv, ff. 150r.-152v.

${ }^{32}$ BL Cotton MS Otho B xiv, ff. 154v., 157r. For other examples see ff. 150v., 160v., 188v.
} 
forbidding the purchase of churches, tithes, villages and seigneurial dues from mills ${ }^{33}$, such assets could not match estates better-suited to sheep husbandry, which could be employed in meeting the rising costs of the convent.

The monastic precinct at Pipewell stands 107-114 metres above sea-level. The main bulk of its estates straddles the border between Northamptonshire and Warwickshire southwest of the abbey, covering the heathland which rises to 200 metres near Cold Ashby before sloping down to the banks of the Avon north of Rugby. The majority of its granges are situated in this area and enjoyed sizeable pastures and sheepfolds. Alongside the home granges of East Grange and West Grange, two main groups stand out: a Northamptonshire upland cluster containing Braybrooke, Cold Ashby, Elkington, and Winwick; and a Warwickshire riverside cluster of Rugby, Newbold, Dunchurch, Cawston, and Church, Little, and Long Lawford. In Northamptonshire, the monks pastured 180 of Richard de Hensa's ewes with their own sheep early in the thirteenth century at Yelvertoft, while in Winwick Randolph de Blockeville granted them pasture for 720 sheep. ${ }^{34}$ Nearer the abbey, 120 sheep were pastured at Oakley and a further 250 of the abbey's beasts at Benefield. ${ }^{35}$ In Warwickshire, 300 ewes grazed at Bilton and another 300 on Cawston Heath, while at Long Lawford there was pasture for 1000 sheep. In the first half of the thirteenth century, 200 sheep from their sheepfolds at Marram were held with sheep of the lord of Rugby. ${ }^{36}$

In total, evidence survives of pasture for over 3000 sheep. Translating this into production capacity is difficult, however, and should not be taken as an upper or lower limit. Cartulary figures of grants of pasture do not translate into flock size, as fluctuations in climate and disease shaped flocks, which often dipped below this number. No evidence survives, moreover, of the weights and measures used at Pipewell and even locally there were variations from the accepted sack weight of 26 stones, at $14 \mathrm{lbs}$. per stone. In 1290, two Londoners sold six sacks to the Riccardi from the pastures of Rothwell, in which

\footnotetext{
${ }^{33}$ Outlawed as early as 1134: Statuta, I, 14-15. For Pipewell's seigneurial instruments: E 326/2655, 2706, 2712 (vills of Newbold, Little Lawford, Harborough); E 326/8825, E 329/188 (tithes in Cold Ashby); E 327/55 (Cold Ashby, Elkington and Thornby); BL Cotton MS Otho B xiv, ff. 157r. (mill at Oakley), 158v. (Rugby), 159v. (Roxton, Barford, Desborough, Little Lawford), 160r. (Church Lawford), 163r. (Rothwell), 183v. (Winwick).

${ }^{34}$ BL Cotton MS Caligula A XIII, f. 43r.; Otho B xiv, f. 183v.

${ }^{35}$ BL Cotton MS Otho B xiv, f. 164r.

${ }^{36}$ BL Cotton MS Caligula A XIII, f. 80r. (Bilton); Otho B xiv, ff. 157v. (Cawston Heath), 191r. (Marram, Long Lawford).
} 
hundred Pipewell lies, and each sack was to contain 30 stones at 13 lbs. per stone. ${ }^{37}$ While Lloyd has calculated the average fleece size as something just under 2 lbs., variations in breed, climate, pasture, and nutrition created a lack of uniformity. ${ }^{38}$ Even with these qualifications, possible flock size and capacity can be assessed. An average sack of standard weight probably contained 200-260 fleeces. ${ }^{39}$ For Pipewell to have filled the twenty-four sacks they promised to the Cahorsins from their own sheep would require around 5500 sheep. But a more realistic contemporary estimate by a Florentine merchant puts annual output at fourteen sacks, commensurate with a flock of just over 3000 sheep. ${ }^{40}$ To put this into context, Meaux (Yorks.) kept a flock touching 11000 in 1280, Rievaulx had over 5000 by the same year, Kirkstall around 6500 by 1320, while the Benedictine fenland behemoth, Crowland, boasted 16000 sheep before scab hit in the 1270 s. $^{41}$ Converting these into annual output Pegolotti gives respective totals of twentyfive, sixty, twenty-five, and thirty sacks. ${ }^{42}$

It was clear, therefore, that both locally and nationally abbots of Pipewell possessed a marketable commodity of high quality. Medieval wool pricing evidence, the main arbiter of quality, is sparse however. ${ }^{43}$ Fortunately, two price schedules for wool marketed by monastic producers survive and both, when taken with the contract, suggest that, while Pipewell never attained the front rank in production, its wool was among the most respected.

Sometime in the late-1330s Francisco Balducci Pegolotti, a leading light in the Bardi company of Florence, prepared a handbook for merchants trading across Europe. Drawing on his experience as a Bardi agent in London from 1317-21, which included the agreement of at least one contract with Pipewell in $1318^{44}$, and on information dating to the $1280 \mathrm{~s}^{45}$, he inserted a list of 200 British monastic wool

\footnotetext{
${ }^{37}$ E 159/63, rot. 25d; E 368/61, rot. 29. Advance Contracts, no. 119.

${ }^{38}$ T.H. Lloyd, The Movement of Wool Prices in Medieval England (Economic History Review Supplement 6: Cambridge, 1973), 2.

${ }^{39}$ The Augustinian prior of Wroxton (Oxon.) sold 1820 fleeces to the Spaniard, Peter de Mundenard, in 1280, laden into six sacks of 260 fleeces each: E 13/8, m. 15d. Advance Contracts, no. 44.

${ }^{40}$ Francisco Balducci Pegolotti, La Pratica Della Mercatura, ed. Allan Evans (Cambridge, Mass., 1934), 262.

${ }^{41}$ Bryan Waites, 'Monasteries and the Wool Trade in North and East Yorkshire during the $13^{\text {th }}$ and $14^{\text {th }}$ Centuries,' Yorkshire Archaeological Journal 52 (1980), 112; Jamroziak, 'Rievaulx Abbey,' 208; Barnes, Kirkstall Abbey, 40; Eileen Power, The Wool Trade in English Medieval History (Oxford, 1941), 35.

${ }^{42}$ La Practica Della Mercatura, 260, 268.

${ }^{43}$ Lloyd, Movement of Wool Prices; J. H. Munro, 'Wool-Price Schedules and the Quality of English Wools in the Later Middle Ages, c. 1270-1499,' Textile History 9 (1978), 118-69.

${ }^{44}$ CCR, 1318-23, 94.
} 
producers with prices for 194 of them. ${ }^{46}$ They include seventy-seven Cistercian monasteries and nunneries. Its good wool being valued at twenty-two marks, Pipewell ranks ninth among Cistercians. Only two other houses nationwide surpassed this value, confirming Pipewell's position within the top 6\% of monastic wool producers. Pegolotti, however, explicitly states that his prices are those on the Flemish market and that the costs of carriage and a good profit should be factored in. ${ }^{47}$ His prices may therefore be inflated. But, even if, as Munro suggests, shipping, marketing and taxation charges account for around $20 \%$ of the value of each sack sold in Flanders, the domestic price of Pipewell wool at around seventeen marks (which tallies with the initial lower sale price agreed with the Cahorsins in 1288) would still have competed with other leading wool producers, as an exchequer schedule of 1294 demonstrates. ${ }^{48}$

In June 1294, as Edward I stockpiled assets to finance war with Philip IV in Gascony, he seized the wool of foreign merchants then in England and forced representatives of ten Italian companies to submit details of their current wool contracts to inform him of the finances he could muster. ${ }^{49}$ Their submissions list 133 monastic producers, fifty-seven of which are Cistercian. ${ }^{50}$ Pipewell's absence, however, suggests that Cahorsin cash had secured its wool. Nevertheless, if we were to take seventeen marks as representing the value of each Pipewell sack, it would slot in as eleventh among Cistercians and seventeenth across all Orders. Taking the stated contract value of twenty-one marks raises the abbey to second among Cistercians and third nationwide.

Possibly the earliest surviving indenture for an advance sale of wool, indeed, concerns Pipewell abbey. At Candlemas 1242 Abbot William sold the coming year's clip to two prominent Londoners for an advance of $£ 80 .^{51}$ In so doing, he flouted long-standing Cistercian legislation against the taking of money in advance of delivery of wool, a practice outlawed in 1189 for deals stretching over a year as they threatened to immerse abbeys in debt and embroil them in usury. As the thirteenth century

\footnotetext{
${ }^{45}$ Munro, 'Wool-Price Schedules,' 134-5.

${ }^{46}$ La Pratica Della Mercatura, 258-69.

${ }^{47}$ La Pratica Della Mercatura, 269.

${ }^{48}$ Munro, 'Wool-Price Schedules,' 125.

${ }^{49}$ E 159/68, rot. 82; M.C. Prestwich, Edward I (Newhaven \& London, 1997), 377-81.

${ }^{50}$ E 101/126/7, mm. 11-25. Advance Contracts, Appendix I.

${ }^{51}$ E 327/541. Advance Contracts, no. 221.
} 
progressed, fewer abbots took heed of this prohibition, provoking a restatement in 1277. A year later sales were licensed for longer periods, although payments were only to be accepted for one year. Pressure from abbeys whose flocks were suffering from scab ultimately forced the General Chapter into allowing receipt of larger sums on condition they were applied to reducing debt. ${ }^{52}$ Such flexibility tacitly acknowledged the importance credit had in monastic finances, as abbots had long been accessing privileges to secure their place in the wool market.

As an earlier example of this, on 20 March 1235, Henry III awarded Pipewell freedom from toll, passage, and pontage throughout his realm, which made carriage by road, river, and sea, and thus export, much cheaper. Equally as important was the exemption of sheep from distraint if the abbey possessed other animals or chattels by which debts could be met. ${ }^{53}$ This threw abbots a lifeline in times of impending penury. Both, therefore, made them more attractive to buyers, and were privileges voraciously sought by many Cistercian houses as they became more deeply involved in selling wool. ${ }^{54}$ But, even without them, Pipewell's wool would always have suitors. After the gradual loss of Flemish custom in the wake of the crises of the early-1270s, it must have been reasonable to expect that the liquid capital accompanying Italian merchant companies into England would have found a home at Pipewell. The most successful company under Edward I, the Riccardi of Lucca, who had business connections in most counties, were active in Northamptonshire and Warwickshire. ${ }^{55}$ But, the evidence suggests that Pipewell was sought out by southern French merchants to the exclusion of all others.

Servat, Soliz, Redole, and Briole formed one of a number of fluid merchant partnerships from the region of Cahors in southern France. ${ }^{56}$ For a century their predecessors had imported wine, cables, and cords into England in return for wool, cementing their involvement in the burgeoning cloth trade of the North Sea world. ${ }^{57}$ They had also penetrated the Northamptonshire wool market. In October 1259

\footnotetext{
${ }^{52}$ Statuta, I (1157: 48); III, 169, 175-6, 184 (1277: 30, 1278: 5, 1279: 2.)

${ }^{53}$ Calendar of the Charter Rolls preserved in the Public Record Office, 1226-57 (London, 1903), 198.

${ }^{54}$ Donkin, Cistercians, 85, 189.

${ }^{55}$ E 13/8, mm. 1d., 28; E 159/54, rots. 18, 19, 20; 63, rot. 25d. Advance Contracts, nos. 30-32, 55-58, 119.

${ }^{56}$ T.H. Lloyd, Alien Merchants in England in the High Middle Ages (Brighton, 1982), 95-6.

${ }^{57}$ N.M. Fryde, 'Die Kaufleute aus Cahors im England des 13. Jahrhunderts,' in Kredit im Spätmittelalterlichen und Frühneuzeitlichen Europa. Quellen und Darstellungen zur Hansklehen Geschichte 37 (1991), 25-38. Franz Arens, 'Wilhelm Servat von Cahors als Kaufmann zu London (1273-1320), VJSSWG 11 (1913), 477-514.
} 
Stephen Chaendut sold six sacks of wool 'de patria de Northamtonia' to Imbert Delderoc, William Fresepayn, and Arnaud Griffun, merchants of Cahors. ${ }^{58}$ Such men must have established long-term business contacts, information strands, and local knowledge in many parts of the country, and particularly so once they became resident.

In 1281, Servat and William Tournemire, keeper of the royal mint, were permitted to render their accounts 'according to the custom of the exchequer', granting them the privileged access to speedy jurisdiction which some Italian merchants had acquired. ${ }^{59}$ This would enable them to obtain a prime position in royal financial affairs, as they would be treated as privileged suitors at the Exchequer court, and their debts would be treated as those of the king. Access to the exchequer process ensured a more rapid judgment and recovery in cases of default. Servat later accompanied Anthony Bek, bishop of Durham, on embassies to Norway to negotiate the ill-fated marriage alliance between Margaret, heiress to the Scottish throne, and Edward of Caernarfon, heir to the throne. ${ }^{60}$

To have formed an association with such cosmopolitan, well-connected men must have considerably appealed to the monks of Pipewell, offering access to a reliable source of capital and influential patrons. For the Cahorsins, the deal promised a steady stream of high quality wool at a constant price. And yet, neither supply nor demand were so weak as to force them together. Both parties could surely have persuaded others to undertake such serious investment. We should look more deeply into the reasons behind their relationship.

Traditionally, recognisances such as that of November 1288 have been viewed as results of successful prosecutions by merchants desperate to recoup their investment against defaulters. In an era of recurrent sheep scab, a skin disease rendering fleeces useless, merchants used the mechanisms of the exchequer either to compel monastic communities to honour their bargain by binding themselves, the house, and their successors, effectively mortgaging their future, or to submit to penalty charges. This seems applicable to the arbitrated settlement of February 1291. Lloyd, however, argues many such

\footnotetext{
${ }^{58}$ E $159 / 33$, rot. 2d. Advance Contracts, no. 3 .

${ }^{59}$ Arens, 'Wilhelm Servat,' 485; R.W. Kaeuper, Bankers to the Crown: the Riccardi of Lucca and Edward I (Princeton, 1973), 21.

${ }^{60} \mathrm{CPR}, 1281-92,352$
} 
recognisances were 'simple registrations of contracts' recording the mutual obligations of both parties. $^{61}$ This better fits the recognisance of November 1288 where the direct investment in sheep is unusual and, arguably, indicative of longer-term commitment.

By the terms of the original contract, the merchants were to provide 733 sheep to be pastured with the monastic flock. As at Kirkstall, where Henry de Lacy, earl of Lincoln, stepped in after its flock had been annihilated by scab by 1284 , restoring it to a pre-disease level within twenty years, such largescale purchases tend to be associated with restocking in the aftermath of epidemics. ${ }^{62}$ Murrain struck in 1258,1277 , and 1283 , decimating flocks nationwide. ${ }^{63}$ While the effect of disease at Pipewell before 1296 is inestimable, twelve miles away at Wellingborough, mortality reduced the flock of Crowland abbey by an annual average of $15 \%$ between 1280 and 1285 , peaking at $20 \%$ in $1281 .^{64}$ Young sheep were particularly badly affected: in $128235 \%$ of the manor's hoggets were slaughtered and in the following year $23 \%$ of lambs died. If such mortality were reflected at Pipewell, the flock would struggle to meet the demands made of it.

To counter this, both parties aimed to create a breeding flock, conditions in the contract stipulating that the imported sheep were to be kept with the abbey's flock until they reached 2000, whereupon they were to be divided equally and wool and issue sold to dual profit. The fleeces of animals dying during any year were to be sold and reinvested in new sheep. Clearly, they had a vision of sustainable stock management to ensure a return on their investment, which was not an overnight development. On 28 June 1280, the rectors of Elkington, Cold Ashby, and Thornby remitted to the abbey exaction of tithes on the produce of all sheep grazing in their parishes, whether the sheep belonged to the monks or to 'certain merchants. ${ }^{65}$ The dorse reveals that these were 'ovium mercatorum de Caturco.' Although these sheep had never yet been pastured in their parishes, this implies that the abbot had negotiated a deal with the merchants and had persuaded the rectors to facilitate the plan. It is possible, therefore,

\footnotetext{
${ }^{61}$ Lloyd, Wool Trade, 292.

${ }^{62}$ Barnes, Kirkstall Abbey, 43-5.

${ }^{63}$ Kershaw, 'Great European Famine,' 27.

${ }^{64}$ Wellingborough Manorial Accounts, AD 1258-1323, ed. F.M. Page (Kettering: Publications of the Northamptonshire Record Society VIII, 1936), 21-46.

${ }^{65}$ E $327 / 55$.
} 
that Cahorsin sheep grazed at Pipewell some years before the first official contract. Such sustained interest suggests that the merchants, far from engaging in transitory business, envisaged a relationship of mutual benefit to both parties.

In an atmosphere of declining production ${ }^{66}$, during which it had been squeezed by the Italian societies, whose international connections and greater liquidity had helped them wrest many wool contracts formerly held by Flemings, the Cahorsin market share was threatened. Financial difficulties may have consequently beset them. At Michaelmas 1287, Arnaud de Soliz received permission to have his debtors distrained to render their debts before the exchequer. On 5 July 1289, Arnaud bound himself and his brother to repay Jean de Redole the arrears of debts he had incurred on their behalf in the Bar fair from 1285. ${ }^{67}$ As his principal security for repayment, Arnaud pledged the wool he had recently bought from Pipewell, even though the date for the first delivery was weeks away. More significantly, during Edward I's Welsh campaigns, Cahorsin merchants had loaned the king around $£ 2800{ }^{68}$ Conversely, the capital investment required for the purchase of Pipewell's wool and in sourcing and buying sheep hints that the contract cannot wholly represent an attempt to buy themselves out of trouble.

From the convent's viewpoint their relationship with the Cahorsins provided short and long term benefits. Firstly, the initial investment perhaps resolved a mounting crisis. In August and October 1277, Pipewell was granted royal protection for one year. Combined with a simultaneous remission of the duty to provide carts to convey victuals to supply royal forces in Wales, this suggests that the king wished to shelter a struggling convent from unnecessary strains. ${ }^{69}$ Secondly, the eventual contract gave the monks a guaranteed market for their best asset at a guaranteed price, a theoretical regular source of income facilitating more ambitious financial planning and exploitation of resources.

\footnotetext{
${ }^{66}$ Wool exports in the late-1280s had fallen to around 25000 sacks a year, a significant drop from over 33000 recorded in 1273 : E.M. Carus-Wilson \& O. Coleman, England's Export Trade, 1275-1547 (Oxford, 1963), 36-7.

${ }^{67}$ E 159/61, rot. 1d; 62, rot. 9d. Advance Contracts, no. 112.

${ }^{68} C P R, 1272-81,214,216 ; C C R, 1272-9,535 ;$ CCh.R, 1277-1326, 215-16.

${ }^{69} C P R, 1272-81,224,234$.
} 
A further drain on resources was provided by Royal and episcopal visits which would have been a common occurrence throughout the period under discussion. ${ }^{70}$ These were a signal honour and lavish hospitality would be expected and dutifully provided, especially when extravagance was occasioned by pride in achievement. For instance, on 5 April 1312, Thomas, earl of Lancaster, and William de Ros of Helmsley headed a huge gathering at Pipewell for the dedication of the abbey churchyard, close, and chapter-house. Commenting on this event twenty years on, Abbot Nicholas sardonically observes that 'no one knows how much was spent on this day.,

This solemn celebration showed off the abbey's new buildings, the abbey church reconstruction having been completed a year earlier. Cistercian architecture progressed apace during the thirteenth century and many abbeys undertook expensive building projects. The sheer scale of such construction brought, as Jamroziak argues, both glory to God and the monastery itself, but equally fuelled those fires of indebtedness which gutted English Cistercian houses late in that century. ${ }^{72}$ Projects of such magnitude nevertheless required long-term planning and financing, a primary part of which must have been founded on the relationship formed with the Cahorsins in the 1280s.

The potentially most debilitating, but most unpredictable drain on monastic finances was the growth of papal and royal taxation during the thirteenth century, which peaked in Edward I's reign. Desperate to supplement the resources available to fund prolonged campaigns in Wales in 1277, 1282, and 1287, the latter of which dovetailed with war in Gascony, and, therefore, to ensure that his most prominent financiers, the Riccardi, retained sufficient liquidity to advance money whenever necessary, Edward himself increased the national tax burden upon all his subjects. ${ }^{73}$ Between 1279 and 1290, he taxed the English clergy on four occasions, to which the Cistercian Order made large contributions, although it was technically exempt. ${ }^{74}$

\footnotetext{
${ }^{70}$ For instance, in 1290 Edward I stayed for about four days at Pipewell. CCR, 1288-96, 143-4; CPR, 1281-92, 381,406 (30 August - 2 September).

71 'Et expensas abbathie illo die factas nemo novit nisi Deus': BL Cotton MS Otho B xiv, f. 197r.

72 Jamroziak, 'Rievaulx Abbey,' 206.

${ }^{73}$ W.E. Lunt, Financial Relations of the Papacy with England to 1327 (Cambridge, Mass., 1939), 311-418.

${ }^{74}$ H.S. Deighton, 'Clerical Taxation by Consent, 1279-1301,' English Historical Review 68 (1953), 161-2.
} 
Obviously, the biggest burden was the contract with Servat, Soliz, and fellows. Possibly conceived at a moment of optimism from a myriad of mitigating factors, the fact remains that the monks reneged on the deal inordinately quickly. It is probable that problems occurred only eighteen months after its inception. At nearby Wellingborough, the summer of 1290 saw the loss of $20 \%$ of Crowland abbey's flock. ${ }^{75}$ Signs that Pipewell had been blighted came as early as January 1291 when the abbot of Warden (Beds.) mainperned to supply five sacks of tayller to the Cahorsins if Pipewell could not. ${ }^{76}$ These negotiations may emanate from the arbitration which Edward I had initiated, possibly at the request of both parties - the merchants keen not to lose their investment, and the convent willing to come to terms to prevent penalties incurred through no fault of their own - which culminated in the enrolment of the arbiters' verdict on 28 February. The king's desire to secure the abbey's future and protect the interests of merchants with whom he had a close financial relationship can be seen in the verdict's enrolment in the chancery and exchequer. ${ }^{77}$ It was perhaps this which persuaded him to stay at Pipewell in the previous September. Indeed, the re-negotiation might originate directly in discussions taken at that time.

The resultant settlement seems skewed heavily in favour of the merchants. It retains the structure of the previous agreement, but includes a variety of punitive clauses which point to the merchants' desire to obtain firmer control of their investment. Now, they were to receive all of the abbey's wool over thirteen years. Tailler wool, which had previously been sorted and packed separately, would be pressed among the remaining wool and, 'for divers trespasses and damages perpetrated against the merchants,' two gratis sacks each year would be taken from the woolsheds. The attached condition that, should the monks default, the merchants would be quit of sixteen marks per sack suggests that these gratis sacks were taken as disguised interest. The same might be said for the forty shillings and three sacks to be taken each year to make up for the merchants' loss of one sack over the previous two years. There is little doubt that the merchants were bitterly disappointed with the monks' investment of

\footnotetext{
${ }^{75}$ Wellingborough Manorial Accounts, 55.

${ }^{76}$ E $159 / 64$, rot. $6 \mathrm{~d}$.

${ }^{77}$ C 54/108, mm. 8d.-9d.; E 159/64, rot. 10; E 368/62, rot. 14. Advance Contracts, no. 133.
} 
their money. Provisions permit them free access to their dresser, whose work was not to be criticised or rejected. They further dictate the construction of new wool storage facilities, ensuring that prepared wool is kept off the ground and well surrounded to ward off damp. The monks' failure to answer adequately for the issues of the 733 sheep originally purchased brought a re-division of the flock. Even though disease had probably intervened, nine hundred of the abbey's sheep were now to be separated from the remainder, marked with the signs of both parties and maintained wholly at the convent's costs until a flock size of 2000 had been reached. While the merchants would take half of the fleeces each year, any sheep dying were to be shorn and the fleeces sold. Profits were to be reinvested in new sheep.

Despite such stinging criticism and the merchants' desire to stamp their will, there remains an air of compromise and cordiality. The investment in sheep continued. The advances essentially remained as before, although it is questionable whether the $£ 120$ advanced upon the sealing of the contract really represented new money, rather than a deduction from the original advance. More importantly, the prices and the potential financial commitment remained stable. In analysing the contract, Franz Arens contends that the merchants benefited by purchasing the wool at a preferential, discount rate (Vorzugspreis). ${ }^{78}$ If Pegolotti's schedule originates from the last quarter of the thirteenth century, this cannot be wholly correct. Even reduced by $20 \%$ for costs of carriage to Flanders and a good profit, Pegolotti's price of twenty-two marks per sack of good wool would bring a domestic price of around seventeen marks, making the Cahorsins offer of twenty-one marks for the bulk of the contract period more than generous. ${ }^{79}$

Having attained a stake in the economic life of the monastery, it is possible that the merchants wished to enjoy the accompanying spiritual benefits. As in 1288 , the merchants were to provide at least one, perhaps two, tuns of wine each year. While this may have been a sweetener to induce the abbot to agree to the merchants' monopoly, or simply a gift, the wine was explicitly presented for the celebration of Mass. Perhaps this was a symbolic offering to expiate the merchants' guilt in levying

\footnotetext{
${ }^{78}$ Arens, 'Wilhelm Servat,' 495.

79 Above, 7-9.
} 
interest. Jamroziak speaks of the Italians who dealt with Rievaulx as outsiders who 'never functioned as a part of the network of mutual obligations which existed locally. ${ }^{80}$ At Pipewell, however, the commitment of the merchants to investing in the abbey and its produce perhaps involved the Cahorsins in ties of patronage. By 1314, and presumably sooner, William Servat acquired five stones of wool each year to put towards the robe he received from the abbot. ${ }^{81}$ Resident in England for around fifty years, Servat had perhaps engaged himself in a more spiritual relationship as a patron of Pipewell, obtaining prayers and a place in the abbey's martyrology.

Unfortunately, this must remain speculation as such evidence does not survive. The same applies to the immediate consequences of the compromise. Nonetheless, the association of Pipewell with the Cahorsins continued until the summer of 1294. With war looming in Gascony and Edwardian finances stretched by the maintenance of English hegemony in Scotland and Wales, Edward I not only banished all men of French blood in England, he exiled many foreign merchants, seizing their wool stocks and trying to appropriate the wool they had contracted for delivery after Midsummer. A surcharge of $40 s$. per sack was placed on the export of wool too. ${ }^{82}$ Although the wool of Italian and Brabanter merchants was quickly released and the merchants rehabilitated, Edward persistently alienated French merchants. At a stroke, Pipewell had been shorn of the guaranteed market for its wool. Worse still, this dovetailed with an economic slump and Edward I's battle to retain liquidity in pursuit of his military aims, which became the immediate catalysts for the collapse of Pipewell's finances.

The imposition of the 40s. maltote and embargoes on trade with Flanders and other French territories enforced in 1294, together with the economic uncertainties flourishing in a period of incipient warfare, brought falling wool prices and a halving of exports in return for a large customs yield. Foreign demand for wool slackened and domestic merchants were hamstrung to an extent by the restrictions on their trade. ${ }^{83}$ The wartime expansion of the national tax burden thus bit increasingly hard on communities struggling to find a profitable outlet for their main asset. In July 1294 Edward

\footnotetext{
${ }^{80}$ Jamroziak, 'Rievaulx Abbey,' 203.

${ }^{81}$ E 159/87, rot. 70. Advance Contracts, no. 190.

${ }^{82}$ E 159/68, rot. 82 (12 June 1294).

${ }^{83}$ Lloyd, Wool Trade, 80.
} 
ordered an investigation into the contents of monastic and cathedral treasuries. Shortly thereafter he successfully demanded the clergy grant half of their taxable income. Having encountered resistance and slow payment, Edward requested another tenth a year later and summoned individual monastic community leaders to attend a special parliament. ${ }^{84}$ While agreeing to meet a national emergency with rebellion flaring in Wales and Scotland, the clerical convocation complained that by the increase in taxation 'the king has exhausted the treasure of the church. ${ }^{85}$

For few communities can this have been truer than for Pipewell, where the growing expense of daily life and estate administration combined with lofty architectural aspirations and the fiscal ambitions of the Crown to impose too great a burden on the monastic purse. There can be little doubt, however, that the spiralling debts owed to the Cahorsins provided the most severe strain. Despite the original potential perceived in their association, for the convent at least these negotiations had brought the abbey to its knees. It may be no coincidence that John de Hillun, who had negotiated the deal, was removed from the abbacy on 1 August 1294, a little over six weeks after the merchants had received orders to leave the country. ${ }^{86}$ So onerous was this burden that the convent petitioned the General Chapter for permission to disperse in $1296 .{ }^{87}$

Ultimately, the convent does not appear to have been dispersed. ${ }^{88}$ But, the petition attests to the financial crisis at the abbey and may have been submitted as part of a plan of austerity introduced by the new abbot, Richard de Heyham, forced upon him by the king. Upon forfeiting foreign merchants in 1294, Edward assumed responsibility for the debts owed to them and demanded the abbey answer him for the Cahorsins' sheep, their issues, and the sale of produce. ${ }^{89}$ This perhaps introduced new urgency into combating debts. It is possible that Edward found the result unsatisfactory for he appears to have

\footnotetext{
${ }^{84}$ Deighton, 'Clerical Taxation,' 172-3, 176-7.

85 'rex thesauros ecclesiae exhausit.'

${ }^{86}$ BL Cotton MS Otho B xiv, f. 155v.; E 159/71, rot. $15 \mathrm{~d}$.

${ }^{87}$ Statuta, III, 286 (1296: 17)

88 ،... a prima domus fundacione usque ad cessionem abbatis Andree [1308] supervenencia nunquam fuit dispersio monachorum in Pipewella facta': BL Cotton MS Otho B xiv, f. 157r.

${ }^{89}$ E $159 / 72$, rot. 23.
} 
taken the abbey's goods into his hands late in $1296 .^{90}$ Whether he also took the abbey into his protection is, however, unclear. Certainly, a series of visitations between 1294 and 1296 had revealed crippling debts and allegations of financial irregularity; there must have been concerns over the abbey's short-term future.

Hillun's removal in 1294 clearly caused a stir. A later enquiry taken in the exchequer at Michaelmas 1297 reveals that he had been removed at the behest of John of York, abbot of Newminster, head of the Cistercian Order in England and father abbot of Pipewell, in the aftermath of a visitation to ascertain the exact level of debt and to establish a plan for repayment. ${ }^{91}$ In the next three years, the abbey had endured visits from prominent abbots of the Order who had established the debt to the Cahorsins at $£ 400$. This suggests that the intervening years from 1291 had witnessed some attempt to meet the abbey's commitment, an impression reinforced by Abbot Richard's answer to a royal inquiry in 1296 that his debt was only £110. Bitter at his removal, Hillun challenged this account, arguing that the established debt of $£ 400$ had thus been concealed from the king. Richard replied that his answer represented a fresh debt, he having accounted with the Cahorsins for the larger sum shortly after his elevation to the abbacy in October 1294. Though further inquiries were taken, the results are unknown, and the case peters out, although Hillun's failure to re-appear before the exchequer barons suggests he had to be satisfied with his successor's riposte.

The years from 1294-9 were anni horribili. Pipewell, a convent in turmoil headed by an abbot held 'in enmity ${ }^{, 92}$ by the Crown, was bound to the king for debts the king perceived as owing to him. A prise of Lent 1297 stripped Pipewell of a further five sacks, five stones. ${ }^{93}$ While the king's consequent debt of $£ 295 s .5 d$. was offset against the $£ 2819 s .8 d$. owed of the arrears of the abbey's debts for the Cahorsins' wool and sheep, repeated petitions only secured the swift repayment promised by the king as early as October 1297, fifteen years later, at Trinity $1312 .{ }^{94}$ Dilatory repayment of this kind was another consequence of Edward I's quest for finances as his military campaign in Scotland fed into

\footnotetext{
${ }^{90} \mathrm{E} 210 / 8474$.

${ }^{91}$ E $159 / 71$, rot. 15 d.

92 'de eius inimicicia hiis diebus': E 159/71, rot. 15d.

${ }^{93}$ Lloyd, Wool Trade, 87-9.

${ }^{94}$ CPR, 1292-1301, 310-11; 1307-13, 289 (23 October 1310); SC 8/297/14816, 315/E196; E 159/85, rot. 26 (Trinity 1312)
} 
renewed strife in Gascony. Repeated requests for taxes set at high rates in 1297 had provoked considerable opposition and had initially induced Edward to threaten his clerical opponents with outlawry and sequestration of their goods. ${ }^{95}$ To avoid this fate, some had paid a fine equivalent to onefifth of their taxable income. Eventually, a compromise was negotiated and writs were issued for the collection of a fifth of clerical income or one-third of their temporalities without exemption. By Summer 1298, Edward was begging Cistercian abbots for aid and not to take money out of the kingdom to general chapters. ${ }^{96}$ Murrain and a series of bad harvests, finally, contributed to the prefamine nadir in the fortunes of the abbey. The accounts rendered to the king demonstrate that in 1296 and 1297 , around $12-15 \%$ of the Cahorsin merchants' sheep were slaughtered due to murrain, a figure which tallies with the $15 \%$ killed at Wellingborough in 1296. Sheep sales were not strong either, Pipewell receiving only $8 d$. per ewe compared with around $13 d$. at Wellingborough. ${ }^{97}$ On the other hand, the value of Pipewell's wool remained high. In 1296 and 1297, 289 and 322 fleeces were sold at $4 s .4 d$. (4.33s.) and $4 s .6 d .(4.5 s$.$) per stone respectively when the national average in these years has$ been calculated as 3.62s. and 3.47s. ${ }^{98}$ Disaster, though, struck in 1299. An inquiry taken in 1306 revealed that of 423 sheep pertaining to the Cahorsins' share kept in the abbot's custody in 1299 only sixteen ewes survived. ${ }^{99}$

Guy Barnes, in his study of Kirkstall abbey remarks, however, on the speed and relative completeness with which the monks were able to recover after the devastation of their flocks and subsequent indebtedness. ${ }^{100}$ Pipewell too, it appears, was able to weather such storms and, when the circumstances changed, flourish again. Old habits and necessities died hard and finances were rebuilt by employing the very measures that had led to the brink of disaster. But, even riding the crest of an

\footnotetext{
${ }^{95}$ Deighton, 'Clerical Taxation by Consent,' 177-87.

${ }^{96}$ CCR, 1296-1302, 216-18.

${ }^{97}$ E 159/72, rot. 23; Wellingborough Manorial Accounts, 67, 70.

${ }^{98}$ Lloyd, Movement of Wool Prices, 40.

${ }^{99}$ E $159 / 80$, rot. 37d.

${ }^{100}$ Barnes, Kirkstall Abbey, 40. The abbey's flock had been decimated in 1284, but had recovered to 4500 by 1301 .
} 
economic boom, there remained an undercurrent of debt incurred through advance sale of wool which would finally cast the abbey into a catastrophe of worse proportions.

The abbacy of Andrew de Royewell arguably represented the apogee of Pipewell's economic fortunes. The ten years from his appointment in 1298 apparently witnessed extensive building projects undertaken and completed and, unquestionably, the acceleration of the construction of the new abbey precinct. Andrew presided over the construction and roofing of the stalls of infirmaries for the monks and lay brethren, the rere-dorter of the great chamber and its vaults. Lavish renovations at Braybrooke produced a new hall, chapel, kitchen, two chambers and a third 'ad purgacionem ventri necessaria.' Although timber was plentiful in and around the abbey for construction, it is doubtful whether building could have been financed in the previous decade and an explanation is required.

Better climatic conditions and good harvests in the early fourteenth century enabled Andrew to create sizeable demesne flocks, herds and grain surpluses. At his death on 8 August 1308 Pipewell possessed sixty ploughs, sixty carthorses and horse-drawn carts, 625 draught animals, 177 milch-cows and 126 calves, ten bulls, thirty-one horses, 330 pigs, and fifty-four goats. According to an estimate made at the time, he bequeathed a surplus of 800 quarters of corn and malt to his successor, which must have eased the task of feeding the convent. ${ }^{101}$ Most revealingly, he had apparently created a flock of 2000 sheep of both sexes with 144 lambs. This would have left the abbey better placed to share in the present boom in the wool export trade. ${ }^{102}$ A recoinage in 1299 lifted prices from the slump produced by Edward I's restrictions on the trade. Before, but most especially after, the Flemish victory at Courtrai in 1302 and the Anglo-French peace agreement of Montreuil in 1303, demand for wool on continental markets rocketed to over 40000 sacks despite the imposition of a new custom on wool exports in 1303.

Of course, it is difficult to take this particular flock figure wholly at face value. Two thousand had been the exact number specified by the Cahorsins in the renegotiated contract of 1291 . The suspicion lingers that the cellarer's account from which Abbot Nicholas received this information may have been invented to match the desired figure. Andrew himself acted as cellarer and the chronicle suggests he

\footnotetext{
${ }^{101}$ BL Cotton MS Otho B xiv, f. 156v.

${ }^{102}$ Lloyd, Wool Trade, 99-100.
} 
'had little wool. ${ }^{103}$ On the other hand, with no corroborative evidence, it cannot be totally gainsaid. Indeed, it may even represent further investment in sheep by William Servat and his fellows. At the very least, it is probably indicative of a real recovery in flock strength at Pipewell. Andrew was apparently able to satisfy a group of Grantham merchants on a ten-year contract made with his predecessor for 100 sacks. ${ }^{104}$ There appears little reason to believe that this would have been the capacity limit. It is inconceivable that the completion of the abbey church could have been achieved without serious capital investment and the probability must be that this had been garnered from the monks' most marketable asset in advance contracts predicated on an expectation of a return on investment.

Dedicated shortly before Easter 1311, the new church symbolised the abbey's rebirth, but the period of buoyancy was woefully short-lived. Signs of another, more serious downward spiral in fortunes were present during moments of prosperity. On 25 June 1310, the new abbot, Thomas de Thockrington, was summoned to appear before the exchequer at the behest of William Servat and Jean de Redole to show why he should not fulfil the obligations to them his predecessor had made. ${ }^{105}$ When he appeared on 10 October, he claimed that he need not answer as the merchants goods had been forfeited as enemies of the king, and that subsequently his predecessor had satisfied the king of all debts. Richard de Heyham, in his account with Edward I, had argued that he had satisfied the merchants before answering the king, but whether he had been acquitted of all such debts is debatable. The exchequer barons adjourned the plea to scrutinise the rolls, but no result is recorded other than seven further adjournments until 1313. Whatever this implies, Thomas was in a weaker position than Servat.

While Edward II shared his father's desire to shield monastic institutions from the worst consequences of economic distress, he too promoted the interests of foreign merchants. Unlike the Frescobaldi forced into exile by the Ordainers in 1311, or Antonio Pessagno of Genoa, Edward's main moneyman thereafter, Servat did not court controversy, but remained a reliable financier worthy of

\footnotetext{
103 ،... set lanas minime.'

${ }^{104}$ BL Cotton MS Otho B xiv, f. 156r.

105 E 13/34, m. 13.
} 
reward. It is probable that, due to his prior good service, Servat had enjoyed a much briefer alienation from Edward I in the late-1290s than other Cahorsins. ${ }^{106}$ After the turn of the century he took on much greater proximity to the Crown. Having been pardoned for clipping coin in 1300 , he became one of the chief mercantile provisioners for the royal household, specialising in wine, spices and wax. ${ }^{107}$ In return, he gained access to the issues of the new custom across a number of ports in 1303 , the traditional method of royal debt repayment, a sinecure Edward II was only too happy to extend repeatedly. ${ }^{108}$ It is doubtful, therefore, that recouping his investment made over twenty years ago at Pipewell was critical to his survival. Nevertheless, as we have seen, this had been no ordinary investment and Servat may well have exploited his position as 'king's merchant' to secure a return.

The continued adjournments probably concealed negotiations between the two parties, for Servat and Redole persisted in their attempts to broker a settlement. A petition submitted in April 1314 complained that, though they had been satisfied in $£ 69$ at the outbreak of Anglo-French hostilities in 1294, the monks claimed this during the merchants’ forfeiture and concealed another $£ 1326 s .8 d$. which had been advanced to them. ${ }^{109}$ Requests for scrutiny of the exchequer rolls, which experience may have told them would find little, were soon reinforced, however, by a direct plea to Edward II's father-in-law, Philip IV of France, who encouraged settlement. ${ }^{110}$ Stung into action, Edward recalled Thomas de Thockrington before the exchequer and on 11 June Servat and Redole acknowledged their satisfaction in all debts owed to them for sheep and wool. ${ }^{111}$

This, of course, was a neat legal fiction. No money changed hands, for in reality it entailed a second, far more realistic restructuring of the original wool contract of 1288 . Only twenty-two sacks were to change hands over eight years, two sacks in each of the first two years and three in the remaining six. The sack price of fifteen marks probably represented both a penalty and recent price deflation. Three stones of clack and locks were to be extracted from each sack and replaced by good wool, ensuring a

\footnotetext{
${ }^{106}$ Lloyd, Alien Merchants, 96.

${ }^{107}$ CPR, 1292-1301, 557, 558; 1307-13, 461; CCR, 1302-07, 3, 8-9, 48; CFR, 1272-1307, 493; 1307-19, 50-1, $70,133$.

${ }^{108}$ CFR, 1272-1303, 472-3; 1307-19, 70 (August 1310); CPR, 1307-13, 270 (July 1310).

${ }^{109}$ E 159/87, rot. 26d.; SC 8/279/13919, 318/E319, E327.

${ }^{110} \mathrm{SC} 1 / 34 / 16$

${ }^{111}$ E 159/87, rot. 70. Advance Contracts, no. 190.
} 
delivery of higher than normal quality. An advance of $£ 213$ was probably paid as a sign of the merchants' good faith, repayable in annual instalments of $£ 2612 s .6 d$., while another $£ 40$ was to be forwarded in the quinzaine of Easter, which was to be allowed in the delivery of wool. Although the prepared wool was to be handed over at Pipewell, the monks were charged with carriage to Boston, possibly to make use of their toll exemptions. Another 1000 sheep of both sexes were purchased to be placed with the abbey's flock to create a breeding flock as before, but this time of only 1500 . Each year the fleeces were to be divided and sold to be reinvested in more sheep.

This is remarkable testament to both parties' continued faith in the potential of their association. For William Servat, this was a closing gambit in a campaign he had waged for over twenty years both to secure his own investment and to lift the monks out of trouble. Although they had been accused, and perhaps not without justice, of default, the monks were willing to deliver five stones of wool each year to William Servat for his robe, thereby tacitly recognising his position as an important patron with the mutual obligations that conferred. As on previous occasions, the monks may have accepted cash at a time of crisis, praying that, with the investment in sheep, they could deliver. It may well have partly been this reluctance to cut its losses which brought Pipewell to disaster, though impending environmental catastrophe and dire necessity played their part.

The new contract of June 1314 was sealed prior to the most severe agrarian crisis within living memory. ${ }^{112}$ Poor harvests at the end of the first decade of the new century had brought grain scarcity and higher prices. Thomas de Thockrington had been compelled to purchase poor quality grain at high prices (20s. a quarter) as Pipewell's estates failed to meet demand. ${ }^{113}$ Bread was rarely baked in the abbey's ovens and had to be carted from Coventry. By Midsummer 1314, the climatic indicators of impending disaster had multiplied. The harvest was unusually poor and crops rotted after heavy downpours throughout Spring. Crowland abbey saw its flock shrink by $28 \%$ - over 3000 in number - in a new

\footnotetext{
${ }^{112}$ Kershaw, 'Great European Famine,' 6-14.

${ }^{113}$ The national average for the first decade of the century was $5 s .71 / 4 d$. a quarter and had reached $8 s$. by the autumn of 1315 , which suggests this estimate may be an exaggeration.
} 
epidemic of murrain. ${ }^{114}$ As in the 1280 s, the deal with Servat could have been a pre-emptive gamble to combat the disease by slaughter of affected animals and consequent restocking.

The combination of murrain and worsening famine caused by persistent rains and the consequent disastrous harvests over the next two summers ensured that the gamble failed. In the seven summers after 1314 only one produced corn good enough to be milled. In an attempt to resolve their dilemma, the abbot successfully petitioned Edward II for licence to assart, enclose, and bring into cultivation royal wastes in Rockingham forest. ${ }^{115}$ Pipewell's abbots had long brought marginal lands under the plough. ${ }^{116}$ But, by the fourteenth century, the fragility of their arable economy had repeatedly been exposed, implying that their search for fresh, cultivable land had increasingly taken them into areas less and less conducive even to subsistence-level agriculture. The monks were left to trawl local markets and producers, placing severe strain on the monastic budget. In 1316, the year of worst dearth, grain sold nationwide for upwards of 26s. $8 d$. a quarter, but at Leicester market, which John de Oudeby, the abbey's pantler, was forced to patronise, occasionally only one quarter of wheat would be sold, fetching $40 s .{ }^{117} \mathrm{~A}$ more general murrain also ravaged sheep flocks from 1315-17, meaning that the monks could hardly generate income, could not fulfil contracts and were compelled to incur greater obligations to creditors.

Hamstrung by inadequate demesne production, but bound by obligations to patrons and the poor in maintaining chantries and distributing alms, Pipewell abbey became trapped in a vicious circle of debt. It was not alone. Ian Kershaw has calculated that in 1316, over 100 grants of royal protection were issued to penurious monastic institutions. ${ }^{118}$ Neither was it alone in the methods it employed to extricate itself. Despite Servat's purchase of all of the abbey's wool for eight years in 1314, Thockrington nevertheless finally and definitively flouted this monopoly and took money wherever he could find it. His wool attracted suitors from the elite of the Italian mercantile financier community and, although a swift recovery in flock numbers could hardly have occurred by 1317 , more clement climatic conditions in that year and the next perhaps persuaded them that they could access a reliable source at a time of shortage.

\footnotetext{
${ }^{114}$ Kershaw, 'Great European Famine,' 22.

${ }^{115}$ CFR, 1307-19, 235 (12 March 1315).

${ }^{116}$ BL Cotton MS Otho B xiv, f. 151v.

${ }^{117}$ BL Cotton MS Otho B xiv, f. 157r.

${ }^{118}$ Kershaw, 'Great European Famine,' 30. Pipewell is not amongst them.
} 
Over the next four years Pipewell eased its cash-flow crisis by negotiating sizeable advances on the back of its best asset.

On 20 July 1319, the English factors of the Bardi company of Florence purchased eighteen sacks at $£ 10$ each - the same price as Servat had paid - and perhaps paid 120 marks in advance. ${ }^{119}$ This connection continued a year later when Manento Francisci, former head of the company's operations in England, purchased twenty sacks at $£ 10$ a sack. ${ }^{120}$ Of course, as with all wool contracts throughout the period in question, the possibility remains that no wool was intended to change hands and that the sum paid in advance was purely a loan which might be repaid in wool, but could be repaid in cash. Although Francisci nominally contracted for twenty sacks, he accepted repayment of $£ 200$ in cash. At the same moment as the Bardi purchased eighteen sacks, Banquino Bruneleschi of Florence loaned Pipewell eighty marks. ${ }^{121}$ On 22 April 1320 the king's Italian leech, Poncio de Controne, Peregrino Bonoditi de Controne, and Niccola Filippi of Lucca forwarded £200. On the same day Bindo Gili of Florence advanced $£ 73$, while a day later the Francisci brothers had their recognisance for $£ 200$ enrolled. ${ }^{122}$ Two months on, Manento Francisci combined with another Florentine, Giovanni Marsopini to lend $£ 400 .{ }^{123}$ None can be positively linked to sales of wool.

Nevertheless, the evidence suggests contracts should be taken at their word and that the merchants were keen to exercise claim to depleted monastic wool stocks. Pipewell apparently delivered eleven sacks to Francisci and eight to the Bardi. Advances at this time may, in fact, have established preferential delivery of wool if and when stocks recovered, and may even have been loans to accelerate the recovery process in the meantime. A year before their first wool contract, the Bardi had forwarded 100 marks, while just two months before he purchased twenty sacks, Francisci had loaned the abbey $£ 100 .{ }^{124}$ On a national level, Italian loans to Cistercian and other notable wool-producing abbeys pre-dominate and

\footnotetext{
${ }^{119}$ BL Cotton MS Otho B xiv, f. 158r. A recognisance for this latter sum was enrolled on 23 July: E 159/92, rot. 88d.

${ }^{120}$ BL Cotton MS Otho B xiv, ff. 157v., 195r. (13 April 1320).

${ }^{121}$ E 159/92, rot. 88 (21 July 1319).

${ }^{122}$ E159/93, rot. 59.

${ }^{123}$ CCR, 1318-23, 241.

${ }^{124}$ CCR, 1318-23, 94 (Bardi, 22 July 1318), 223 (Francisci, 28 February 1320).
} 
some recognisances specify advances are 'loans' to be put to the use of the convent. ${ }^{125}$ While this is rather vague and may equally refer to simple sustenance, the quicker monasteries were able to right their finances and stocks, the quicker the floundering wool trade might recover and debt could be serviced.

The European famine caused a dramatic slump in wool demand and exports ran at under 20000 sacks a year in 1315. It struck in the wake of English defeat at Bannockburn in June 1314 and mingled with Edward's abortive attempts to regain hegemony in Scotland and Ireland, where Edward Bruce invaded and proclaimed himself king in May 1315, and subsequent rebellions in Glamorgan and at Bristol in 1316. ${ }^{126}$ For many of the Italian financiers at Edward II's court, these dual prongs strained finances, for he demanded larger loans and purveyances to fund his war efforts. ${ }^{127}$ Between 1312 and 1315, for example, Manento Francisci had already received assignments from the exchequer of issues worth over $£ 15000$ in return for loans to the king as the chief Bardi factor in England. ${ }^{128}$ In 1316, he was commissioned to provide 700 quarters of wheat for the Scottish campaign. ${ }^{129}$ His successors, led by Roger Ardingelli and Francisco Balducci Pegolotti, kept Edward solvent for the remainder of the decade, making huge individual loans, such as the 10000 marks advanced in November $1317 .^{130}$ Their rewards were tangible, chief among which was almost monopolistic assignment from the wool customs. ${ }^{131}$ Assisting struggling monasteries, many of whom particularly in the Cistercian Order were among the leading producers of the best quality wool in the British Isles, thus made obvious sense.

Pipewell was merely one link in these chains of credit. The Bardi were certainly prominent creditors in Northamptonshire and Warwickshire, lending $70 m 6 s .8 d$. to Sulby shortly after its first surviving loan to Pipewell and eighty marks to Combe in August $1319 .{ }^{132}$ They were also active elsewhere, Francisci

\footnotetext{
${ }^{125}$ E 159/91, rot. 73d. - loan of $£ 140$ (18 October 1317) by Banquino Bruneleschi of Florence to Bruern 'ad ardua negocia domus sue inde expedienda'; E 159/92, rot. 60d. - loan of eighty marks (1 August 1319) to Combe 'pro arduis nostris negociis domus et ecclesie nostre inde expediendis et promovendis.'

${ }_{126}^{126}$ R.M. Haines, King Edward II: His Life, His Reign and its Aftermath, 1284-1330 (Montreal, 2003), 98-101, 289.

127 The mission of Roger Mortimer to Ireland in April 1317 was partly financed by Antonio Pessagno of Genoa and the Bardi: CPR, 1313-17, 608 .

${ }^{128} C C R, 1307-13,403,405-6,407$; 1313-18, 33, 114, 118, 121-2, 144-5; CFR, 1307-19, 158, 168, 178, 186; CPR, 1313-17, 11, $19,106-7$.

${ }^{129}$ CCR, 1313-18, 383.

${ }^{130} C P R, 1317-21,55,59$.

${ }^{131} C P R, 1313-17,608,672-3 ; 1317-21,9,11,15-16,127 ; C C R, 1313-18,492$.

${ }^{132}$ E 159/92, rots. 60d. (28 July 1318), 89.
} 
advancing 200 marks to Vaudey on the day before he loaned Pipewell $£ 200 .{ }^{133}$ Bruern took $£ 15417 s .4 d$. from the Bardi on 20 October 1317, two days after it had received $£ 140$ from Banquino Bruneleschi. ${ }^{134}$ Bruneleschi himself loaned at least $£ 430$ to Sawtry (Hunts.), Warden and the Gilbertine house of Chicksands (Beds.) in November 1317. ${ }^{135}$ What overall effect such a flow of credit in the direction of wool-producing houses had can only be guessed, but between 1319 and 1321, wool exports rose to over $30000 .{ }^{136}$

So acute were the financial problems at many houses, however, that the credit expansion created as many problems as it attempted to resolve. Loans had to be repaid and often at harsh terms. Pipewell's loans from Controne and Gili had to be met within eight months. Debts were increasingly incurred to service other credit obligations and the consequences could be drastic, particularly when the better harvests of 1317 and 1318 and the retreat of the sheep murrain proved false dawns as the rains returned and with them rinderpest, which decimated stocks of draught animals across the country. ${ }^{137}$ Crops rotted in the fields and a subsistence crisis ensued.

In January 1320 Pipewell endured a visitation from John of Whelpington, abbot of Newminster. ${ }^{138}$ He established Pipewell’s debt at $£ 46920$ s. 10d., around the level it had been in 1296, permitting the monks to sell the abbey's goods to meet debts. The abbey chronicle reveals that this would have availed them little, for the full extent of their debts had been concealed from their visitor, a marginal note estimating the true total at $£ 11183 s .4 d$., which is a more accurate assessment. Whether such deceit or more general despair at his decision-making brought about the deposition of Thomas de Thockrington on 1 January 1321 is difficult to say. ${ }^{139}$ His strategy of taking Italian silver did bind the abbey to outside forces and made extricating it from ever decreasing circles of debt more problematic. In an effort to meet contract obligations to foreign merchants the abbey had purchased wool worth 100 marks from Roger

\footnotetext{
${ }^{133}$ E 159/93, rot. 58 (12 April 1320).

${ }^{134}$ E 159/91, rots. 73d., 74.

${ }^{135}$ E 159/91, rots. 75d., 77, 77d. This small list does no justice to the number of recognisances on the Memoranda Rolls in 131720, which highlight monastic credit relationships across most orders and in most counties of England and Wales.

${ }^{136}$ Lloyd, Movement of Wool Prices, 18.

${ }^{137}$ BL Cotton MS Otho B xiv, f. 160v.

${ }^{138}$ BL Cotton MS Otho B xiv, ff. 157v.-158r.

${ }^{139}$ BL Cotton MS Otho B xiv, f. 194r.
} 
Belers, a local Leicestershire landowner and retainer of Thomas, earl of Lancaster, cousin and most prominent critic of Edward II. Belers extorted a $£ 100$ annuity from the abbey and a pledge of the granges of Elkington and Cold Ashby. ${ }^{140}$ Furthermore, in November 1321, Giovanni Marsopini and Asselino Simonetti of Lucca loaned 200 marks to have first refusal on the abbey's goods to be sold off to meet its debts. ${ }^{141}$ The vultures, it appeared, were now circling.

Despite an initial determination to meet his predecessor's obligations, William of Lawford, the new abbot, soon succumbed to debt. In the first month of his rule he procured the cancellation of the recognisances to the Contrones and Bindo Gili, wiping $£ 273$ from calculation. ${ }^{142} \mathrm{He}$ was also able to deliver eleven sacks to Francisci and eight of the eighteen sacks owed to the Bardi. It is worth remembering, though, that such cancellations did not necessarily imply full payment. Francisci only finally agreed to annul his agreement three years after it had technically been settled in August 1323. The Bardi, moreover, exacted a penalty of $£ 40$ for a false weighing of the delivered wool and for failure to carry it to the delivery point at Stamford, although they were willing to loan a further $£ 50$ on 9 February 1321. ${ }^{143}$ This last loan highlights the quandary into which every abbot of Pipewell had fallen over the past forty years - no matter how straitened the circumstances, the repeated acceptance of liquid capital to sustain the brethren and their obligations made the light at the end of the tunnel seem closer irrespective of the likely consequences. For Lawford, though, these consequences brought scandal and lasting infamy.

He was singularly unfortunate that his elevation to the abbacy coincided with the worst of the crisis years. Another deluge had ruined the harvest in 1320, while drought brought renewed crop failures and famine in $1321 .{ }^{144}$ Wool exports slumped to only 18000 sacks. ${ }^{145}$ The only solution apparent was that

\footnotetext{
${ }^{140}$ BL Cotton MS Otho B xiv, f. 186r.: 'ad opus domini Rogeri Boler cui domus tenebatur in c marcis ... pro lanis ab eodem emptis ad opus mercatorum.' For Belers, see N.M. Fryde, Tyranny and Fall of Edward II, 1322-6 (Cambridge, 1979), 101-4. ${ }^{141}$ E 159/95, rot. 39d.; BL Cotton MS Otho B xiv, ff. 159r., 196r.

${ }_{142}$ BL Stowe MS 937, f. 143r.

${ }_{143}^{14}$ BL Cotton MS Otho B xiv, f. 158r.; E 159/94, rot. 67d.

${ }^{144} \mathrm{P}$. Nightingale, 'Norwich, London, and the regional integration of Norfolk's economy in the first half of the fourteenth century,' in Trade, Urban Hinterlands and Market Integration c. 1300-1600, ed. James Galloway (London: Centre for Metropolitan History Working Paper Series 3, 2000), 94.

${ }^{145}$ Lloyd, Movement of Wool Prices, 18.
} 
proposed by the abbot of Newminster in 1320. The abbey's assets had to be sold off for the brethren's survival.

Historians have long viewed the early fourteenth century as a watershed in the Cistercian and national agrarian economy. David Knowles commented that the monks were 'gradually going over from direct exploitation ... to rents and leases. ${ }^{146}$ In 1293 the General Chapter legislated to permit land exchanges and alienations without its licence and in 1315 authorised leases to laymen for life if the benefits were manifest. ${ }^{147}$ James Donnelly has argued that leases of granges at Fountains, Furness, Meaux and Whalley, helped finance debt repayments without incurring further charges. ${ }^{148}$ On broader social levels, Barbara Harvey believes that land transactions took place in times of greatest dearth, as sellers attempted to gain sufficient liquidity to survive crises. ${ }^{149}$ At Pipewell, however, the impression is that the loss of the keystones of the economy, whatever the short-term benefit, proved insufficient to improve the abbey's finances.

The abbey chronicle details goods sold off to service debts ${ }^{150}$ : wool worth $£ 30$; the produce of fishponds worth $£ 19$; five large basins for $£ 7$; the produce of felling trees worth $£ 110$. More seriously, demises for immediate profit reduced the income-generating capacity of the abbey's demesne and seigneurial rights and brought in less than expected. Two barns at Braybrooke and Dunchurch were sold for $£ 20$, while 20s. accrued from the sale of a cowshed at Dunchurch. At Marham the monks intended to demise their land to Robert of Lawford for 26s. 8d., but 'propter sterilitatem' at Easter 1321 he would only pay 20s. Conversely, Robert purchased the mill at Church Lawford for eight quarters of grain and an annual mulcture, but made material improvements, spending more than the monks on repairs.

The most instantly profitable demise came on 3 November 1321, the very day upon which Simonetti and Marsopini asserted their right to first refusal on the abbey’s goods. ${ }^{151}$ After considerable wrangling in London and a dispute with the convent over its sale, Augustine le Waleys received possession of the

\footnotetext{
${ }^{146}$ Knowles, Religious Orders II, 126.

${ }^{147}$ Statuta, III, 261 (1293: 2), 330 (1315:4).

${ }^{148}$ Donnelly, 'Changes in the Grange Economy,' 426-42.

${ }^{149}$ Barbara Harvey, 'Introduction' in B.M.S. Campbell (ed.), Before the Black Death. Studies in the "crisis" of the early fourteenth century (Manchester, 1991), 14.

${ }^{150}$ BL Cotton MS Otho B xiv, f. 158v.

${ }^{151}$ BL Stowe MS 937, f. 22v.; Cotton MS Otho B xiv, ff. 186v.-187r.
} 
grange of Cold Ashby, rendering $£ 180$ in advance. Apart from this lump sum, this sale is significant as it perhaps marks a sea-change in the abbey's attitude to finance and a longer-term search for more local patrons better placed to reduce the charges on the monks. On 14 February 1321 Abbot William demised the grange at Elkington to William Tekne, burgess of Northampton. ${ }^{152}$ Elkington suffered badly during the famine years and could no longer support more than a handful of the abbey's beasts. ${ }^{153}$ In return for William's commitment to undertake repairs and, more importantly in the immediate short-term, a loan of grain, malt, and ale, worth $£ 100$, the grange was demised to him rent-free for a term of nine years.

Disquiet in the convent about this sale prompted the negotiation of a new lease. In return for establishing the abbey’s debt to him for foodstuffs at $£ 200$ in the court of the King’s Bench, William received the grange for nine years at an annual render of ninety marks, as well as forty quarters of corn in the first year, fifty quarters in the second, and sixty year on year for the remaining seven years. Throughout this term, moreover, William was to find pasture and fodder for 300 ewes and their issue at Calewelhilcote. Sheep, after all, were the lifeblood of Pipewell's economy. William Servat died in 1320 and with him any hope of further Cahorsin investment in the abbey's stock at a time of real desperation. Nevertheless, this did not deter Pipewell from seeking patrons willing to enter into a business relationship of this kind.

On 8 June 1321, Abbot William demised the grange of Newbold-on-Avon to John and Henry, sons of Hugh de Merynton, merchant of Coventry, at an annual rent of $£ 8 .{ }^{154}$ By July 1322 , he appears to have granted Hugh $£ 20$ of annual rent from Cawston and Dunchurch granges. He also leased the manor of Cawston for $£ 40$ on condition that Hugh manage grain production and pasture, but only take his profit in corn, hay, and grass after the abbey had repaid him this sum, thereby passing the costs of production onto a party with greater liquidity, but without prejudicing their subsistence needs. ${ }^{155}$ Coventry lies a short distance from Pipewell's Warwickshire granges and Hugh had moved into the abbey's orbit over a number of years. Around the time of the initial demise of Newbold, Hugh received from the Bardi the abbey's as yet unfulfilled obligation for twelve of the eighteen sacks Thomas de Thockrington had agreed

\footnotetext{
${ }^{152}$ BL Cotton MS Otho B xiv, ff. 160v., 187v.

153 ' $n e c$ fuit tunc aliquis monachus vel conversus qui voluit scivit vel potuit custodiam dicte grangie adviter sine auxilio magno bursa communis et sumptuoso.'

${ }^{154}$ BL Cotton MS Otho B xiv, f. 190r.

${ }^{155}$ E 326/8934.
} 
to deliver in July $1319 .{ }^{156}$ Shortly thereafter Abbot William agreed to sell Hugh sixty sacks of wool and sixty fleeces over the next ten years. ${ }^{157}$ This may equate with the contract related in the abbey chronicle for forty-five sacks, at ten marks a sack, over seven-and-a-half years. ${ }^{158}$ Revealingly, this contract committed the monks to paying Hugh and his wife an annuity of 40s. in return for his purchase for them of 100 sheep. An advance of twenty marks was made on condition that the monks re-invest it in the purchase of more sheep.

As with the contract which overshadowed Pipewell's financial dealings during this period, the monks did not invest as they should have done. For all Merynton, Waleys, and Tekne offered, the level of their investment could not offset climatic catastrophe and the crippling level of long-standing debt, as it necessitated the removal of production units from the monastic economy and the consequent obligation for further debts. On 28 April 1322, Edward II took Pipewell into his protection. Just under a year later, on 24 April 1323, William of Lawford, presumably pressured by monks nourished only by black bread and potage and despairing of a revival in the abbey's fortunes, resigned his rule. Only four months later, on 13 September, 'per ... pondera oneris domus sancte Marie pervenit ad ultimum punctum inedie ac paupertatis', and was dispersed for three years. ${ }^{159}$

In her study of the late thirteenth century bankruptcies at Rievaulx, Emilia Jamroziak not only dispels the notion that the monks' ill-fated forays into the wool market represented a growing departure from the Cistercian orthodoxy, she goes a long way in exonerating the convent of the charge of mismanagement. ${ }^{160}$ Cash-strapped monasteries were drawn into marketing their primary saleable asset - wool - to sustain higher living costs, royal taxation, and to fund projects to the greater glory of God and their own community. When environmental calamities and endemic outbreaks of disease combined to decimate flocks, indebtedness became a 'way of life'. Nowhere more than Pipewell would appear to better

\footnotetext{
${ }^{156} C P R, 1317-21,410$. Above, 28.

${ }^{157}$ Two letters of acquittance drawn up in 1324 attest to this agreement, the second stating that the monks had satisfied Hugh for the third year: E 326/8934, 11541.

${ }^{158}$ BL Cotton MS Otho B xiv, f. 161v.

${ }^{159}$ BL Stowe MS 937, f. 143v.; Cotton MS Otho B xiv, f. 150r.

${ }^{160}$ Jamroziak, 'Rievaulx Abbey,' 215-17.
} 
corroborate this argument, but can an assessment of its finances conclude by similarly exonerating the monks?

It is undeniable that the four decades either side of the turn of the fourteenth century represent one of the most turbulent periods in English economic history and of Cistercian involvement in that economy. Pipewell, whose monks repeatedly struggled to raise sufficient surpluses of grain from its increasingly marginal lands, experienced the wide fluctuations between dizzying booms of buoyant demand and good prices for its wool and spiralling lows marked by bovine and ovine pestilence and famine. Taxation too, in adding to the rising burden of debt, threatened to swamp the community with commitments it could not fulfil. It is probably best to let the monks describe the combined effects.

A petition from the abbot and convent tells of the damage wrought by the recent years of dearth and by murrain and of the recurrent threat of dispersal. ${ }^{161}$ In response to the latest tax demand, they claim that their old assessment now exceeds the annual revenue of the lands still in their hands and request they be taxed on what they have, at least until the king has received what is due to him from a lay twentieth. Without re-assessment they would not be able to maintain the chantries and alms with which their founders and patrons had charged them and would have to disperse. ${ }^{162}$ Of course, the monks knew exactly which buttons to press. Exaggerating their case or the possible consequences might tug more firmly at the royal heartstrings. Sadly, this was definitely not the case, the king refusing the request as he 'ad tant a faire de ses deners qil ne les puisse mie respiter.' References to the concurrent clerical tenth and lay twentieth and the ravages over the years date it most probably to 1327/8, making it doubtful that they were cynically manipulating Edward III. ${ }^{163}$ Pamela Nightingale has shown that the years $1325-9$ was one of the worst periods in Norfolk's history with a return of heavy rains and disease - thus is was not just the monks of Pipewell who were struggling with bad

\footnotetext{
${ }^{161}$ SC 8/66/3274: 'la dite meson seyt si enpouery par le [...] annees qe avaunt ses heures ount este e par morine des bestes … 'la quele demaunde amounte a plus qils ne pount despendre par an de totes lour terres en lour mayn demorauntz, par quey sil payent tute la dite demaunde de disme ils ne pount recoverir a longe temps ne lour chaunteries ne autres almoygnes dount $y$ l sount chargez par lour foundours et feffours a meyntenir ne pount mes covent qils mettount lour covent en dispercion.' ${ }^{163}$ W.M. Ormrod, 'The crown and the English economy, 1290-1348,' in Before the Black Death, 161; Lay Taxes in England and Wales, 1188-1688, ed. M. Jurkowski, C.L. Smith \& D. Crook (Richmond, 1998), 36. The only other plausible year is 1316, but references to the demises discussed above, which mainly occurred towards the beginning of the 1320s, militate against this.
} 
weather and murrain. ${ }^{164}$ It is likely that even after its reconstitution, which probably occurred simultaneously with the cancellation of long-standing recognisances to the Bardi in June $1326^{165}$, Pipewell abbey continued to suffer from chronic indebtedness.

It is hard, though, to believe that the monks who submitted this petition could have been wholly forgiving of their predecessors. Their plea emphasises that previous abbots had leased lands and possessions in return for money paid in advance in order, so they said, to evade dispersal. ${ }^{166}$ The convent had witnessed the loss of many of its most valuable production units. Early in Edward III's reign, it negotiated with Thomas Latimer to quash a demise made to him in 1318 of lands in Braybrooke. ${ }^{167}$ Moreover, William of Lawford's confessed submission to temptation in entering into the recognisances which caused the abbey's dispersal served as a salutary reminder to the monks of their forebears' actions and their consequences. Jamroziak questions whether Rievaulx's monks, in simultaneously taking on wool contracts for over eighty sacks a year, an impossible burden, were 'riskloving investors', unscrupulously taking Italian lucre knowing they could fall back on royal protection. ${ }^{168}$ While she answers in the negative, even a fraction of the commitments Thockrington and Lawford entered into from 1317-23 would have been impossible to meet, stock levels falling to terrible lows. In January 1321 Thomas bequeathed his successor only $45 \%$ of the affers, $15 \%$ of the plough oxen, $7 \%$ of the milch-cows and, most importantly, 33\% of the sheep which he had received in 1308 from Andrew de Royewell. By April 1323, William possessed only 54\% of the affers, $21 \%$ of the plough oxen and $43 \%$ of the sheep Thomas had left. ${ }^{169}$ It may have been that they were deceitfully taking money and not using it for the intended purposes.

Abbot Nicholas, or his apologist, certainly looked back on his experiences in the convent during this period with considerable regret. Remarking on the deal with Hugh de Merynton, in which the abbey received twenty marks in advance, he argues that, had it been used to buy more sheep, the

\footnotetext{
164 Nightingale, 'Norfolk, London, and the regional integration of Norfolk's economy,' 94.

165 BL Stowe MS 937, f. 143r.

166 'les predecessours le dit abbe ount lesse lour terres, rentes e possessiouns en [...] mayn ascunz a terme de vye ascuns a lunge terme des annz e pristrent lour deners devaunt la mayn pur lour sustenaunce e pur escure la dispercioun de[..] covent.' 167 BL Stowe MS 937, f. 72v.

168 Jamroziak, 'Rievaulx Abbey,' 214-5.

${ }^{169}$ BL Cotton MS Otho B xiv, ff. 158r., 161r.
} 
church of Pipewell would have considerably benefited. ${ }^{170}$ Accusations of deceit pervade accounts of the abbey's recent history; three abbots resigned, or were forced to resign, their office shrouded in debt and controversy. Richard de Heyham, Andrew de Royewell, and Thomas de Thockrington were also accused of concealing the full nature of their debts, while secret alienations and private sales of timber against the convent's consent are attributed to most of Nicholas's predecessors. ${ }^{171}$ Shortly before the dispersal, too, the abbey apparently succeeded in quashing the Cahorsin contract for only two marks 'per viam dexteram sinistram' after the death of Servat's executor, John de Stoketon. ${ }^{172}$ Even accounting for the chronicle's slanted view of history, successive abbots had long aimed to cast off this debt.

There is little question that the Cahorsin deal was the most important factor behind the financial difficulties faced by Pipewell abbey. It hung in a Damocletian manner over the monks who repeatedly took the Cahorsins' investment, but persistently reneged on their obligations. And yet, it is unlikely that it was a relationship founded on deceit, being instead intended to give both parties long-term security and stability. Formed at a time of stock shortages and disease, this business relationship offered the possibility of establishing a breeding flock to outlast the current crisis and a firmer foundation for future prosperity. ${ }^{173}$ Their quality product enabled the monks to attract investors who were not solely interested in quick returns. Regardless of the financial drain subsequent defaults and legal entanglements caused, investment in sheep purchases and advance payments suggest that the Cahorsins would not forsake the potential profitability of this arrangement. William Servat, moreover, in obtaining a stake in the future direction of the abbey, had perhaps even become bound into the abbey's patronage network. Intriguingly, after the convent's dispersal, a visitation decreed that as the

\footnotetext{
${ }^{170}$ BL Cotton MS Otho B xiv, f. 161v.

${ }^{171}$ BL Cotton MS Otho B xiv, f. 151r.

${ }^{172}$ BL Cotton MS Otho B xiv, f. 155v.

${ }^{173}$ Whilst Pipewell took a risk with its most valuable asset, wool, to attempt to survive, other European monasteries used other creative financial techniques to keep solvent during this period of crisis. For example, a German-Danish house, Klosster Reinbek sold a village to a lay donor in 1316 , and numerous other houses were forced to alienate their property, either for limited periods or in perpetuity: Jordan, Great Famine, 65-67. In modern finance terms these institutions were mortgaging, or on occasion liquidating, their real estate portfolios to access the cash they needed for daily survival.
} 
Cahorsins had not been satisfied the monks would offer daily prayers for them and the rest of their benefactors at the altar of St Michael. ${ }^{174}$

Throughout Pipewell's recent history, therefore, there was unrivalled evidence for a desire to establish a sustainable economy centred on wool production and to attract patrons from a wider community. The Cahorsins were replaced in this scheme by Hugh de Merynton. The downside was the potential this had to throw the monks into the hands of outsiders who did not have their best interests at heart. Bad luck and unrealistic expectations of their flocks drove them into a vicious circle, where their original need for money for subsistence and future expansion were subsumed by the desire to counter increasing poverty and new debts incurred to service old debts; as the circle constricted, they went further and further into trouble. But, although it became 'easy to take, but hard to give', the ends justified the means.

\footnotetext{
${ }^{174}$ BL Cotton MS Otho B xiv, f. 195r.
} 